tons; composite steamers, I09, of an aggregate burthen of 32,820 tons; and wooden steamers, 822 , of an aggregate burthen of 380,655 tons. Of the steamers afloat in $1885,5,792$ were owned by the United Kingdom and its colonies, their aggregate burthen being 6,595,87 I tons. The other countries of the world owned steamers as follows, last year: Germany, 579; France, 509; Spain, 40I ; the United States, 400; Norway, 287; Russia, 2I 2; Denmark, 200; Italy, I73; Holland, I52; Brazil, I4I ; Japan, I05; Greece and Turkey, 82 each; Belgium, 68; Chili and the Argentine Republic, 43 each ; China and Portugal, 27 each ; Hawaii, 2I ; Mexico, I 5 ; and miscellaneous, 50. It will be seen, that, notwithstanding the great depression prevailing in steam-shipping, the number of steamers afloat has increased to the extent of 327 , as compared with 1885 .

- The official returns quoted from the Wochenschrift für Brauerei for the first six months of the current year show the export of a total weight of 64,079 tons, being an excess of 2,789 tons as compared with the same period of $\mathrm{i} 886$, but representing a decrease of $13,28 \mathrm{I}$ tons as against the first six months of 1885 . There has been a progressive export during the earlier part of the last three years to Hamburg, Bremen, Austria, Switzerland, and Sweden, while deliveries to France and Belgium have fallen off. There is an increase this year in exports to Holland and Denmark. Trade with Great Britain and Russia has been larger than in 1886 , although not up to the mark of 1885 ; while there is a decrease in shipments to the United States, Italy, and Spain, as compared with I 886. Imports from Austria were for the three six-monthly periods, was dug up. Four of them are nearly same size, - about seven inches long, one and a half inches wide at broadest place, and about one-fourth of an inch in thickness along the middle line. The fifth is half an inch shorter, one and one-fourth inches in greatest breadth, and nearly half an inch thick. It is hardly so well finished as the other four.

When found, they were all lying close together, their flat sides in contact, and points up, evidently so placed intentionally. They were buried about two feet below the surface of the ground. They are now in my possession.

Fayette, Mo., Sept. 30. J. W. Kilpatrick.

\section{Over-Pressure in the Schools.}

I THINK it is an unfortunate fact that our public-school system is not elastic enough to mould itself to the needs of the individual. Grades are a necessity in it, and grades must be quite rigidly fixed. But I think that the parents can mould the system so that there shall be no over-pressure. A great source of trouble is that the parents often positively encourage the pressure. A mother brought to me her daughter, a shamefully overworked high-school scholar ; no exercise, except the walk to and from school. If this mother takes my advice, and sends word to the teacher, "My daughter is not going to stand at the head of her class any more ; if necessary, she will be honestly and healthily at the foot," the teacher may reply, "Then she cannot graduate, and have a diploma." Then the mother must mould the public-school system to her daughter's needs, and say, "Then she will not graduate. I am content to have

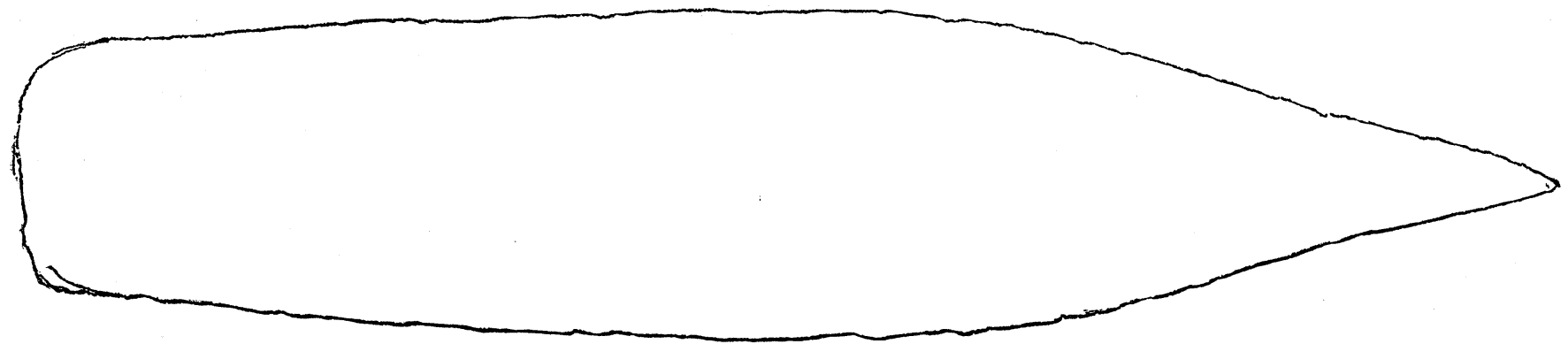

STONE DAGGER FROM MISSOURI.

5,433, 6,236, and 6,829 tons ; and from Great Britain, 404, 44I, and 504 tons. Thus it will be seen imports have, on the whole, been increasing. The imports from Austria have always been much in excess of the exports to that country, but formerly imports from Great Britain were inferior in quantity to the direct exports thither. The quantities were as nearly as possible equalized during the period under review, but it is conjectured that a portion of the beer nominally exported to the Hamburg district was subsequently forwarded to England.

\section{LETTERS TO THE EDITOR.}

* * The attention of scientific men is called to the advantages of the correspondence columns of SCIENCE for placing promptly on record brief preliminary notices of their investigations. Twenty copies of the number containing his communication will be furnished free to any correspondent on request.

The editor will be glad to publish any queries consonant with the character of the journal.

Correspondents are requested to be as brief as possible. The zuriter's name is in all cases required as proof of good faith.

\section{Stone 'Daggers' from Missouri.}

THE following may be worth recording. A few days since, near this place, a farmer, digging to make a pond, in land that has never been under cultivation, found a 'deposit' of five chipped stone 'daggers' (or spear-heads?). I enclose an outline sketch of one the exact size of the specimen. The 'daggers' are of chert, and so much alike in material, that one can easily suppose them made from pieces of the same mass of stone. The workmanship, as inclicated by the finish of the implements, is of superior merit. Each implement is chipped to a sharp edge all around, even at the base. They are all in perfect condition except No. 2, which received small breaks on one side of base and at extreme tip of point as it it so." Perhaps she will not say this, for parental pride is one cause of the over-pressure.

Another cause is parental laziness. It is easy to keep a boy employed evenings by compelling him to stay at home and study his lessons. Otherwise he must either be allowed to choose his own amusement, in the house or out of it (which, of course, is not the best thing), or the parents must have him on their minds, and provide amusements for him, or at least have an oversight of his recreations, which is a trouble. In practice, too many parents either let their children roam the streets at night, or beg the teacher to give their children enough to do, so that they must have some lessons to occupy their evenings.

E. P. KING.

Providence, R.I., Oct. 8.

\section{Silver in Oregon}

I FIND silver in minute quantities in several of the eruptive rocks of north-western Oregon. The upper lava-flows on the Portland Hills contain, as far as I have investigated them, amounts ranging from one-tenth of an ounce per ton (or .0000034 of one per cent) to one-fourth of an ounce (or .0000085 of one per cent). The lava in question is a scoriaceous micro-basalt, very much decomposed in the exposed portions, but becoming sound and hard at a few feet depth.

Specimens of volcanic tufa from an immense deposit in the western foot-hills of the Cascade Range, near the Clackamas River, yield from a 'trace' of silver up to the surprising quantity of six ounces per ton (or .0002 of one per cent).

In the assays I employed the scorification method, using test lead devoid of silver.

Portland, Ore., Sept. 30.

HERBERT LANG. 